\title{
Differences in Morphological, Physiological and Growth Traits between Two Endemic Subspecies of Brassica rupestris Raf.: Implications for Their Conservation
}

\author{
Maria Fiore Crescente, Loretta Gratani \\ Department of Environmental Biology, Sapienza University of Rome, Rome, Italy. \\ Email: mariafiore.crescente@uniroma1.it
}

Received April 10 $0^{\text {th }}, 2013$; revised May 10 ${ }^{\text {th }}, 2013$; accepted June $2^{\text {nd }}, 2013$

Copyright (C) 2013 Maria Fiore Crescente, Loretta Gratani. This is an open access article distributed under the Creative Commons Attribution License, which permits unrestricted use, distribution, and reproduction in any medium, provided the original work is properly cited.

\begin{abstract}
The goal of this work was to analyze the phenological and physiological responses of Brassica rupestris Raf. subsp. hispida Raimondo \& Mazzola and Brassica rupestris Raf. subsp. rupestris to environmental factors also in consideration of global change. We used seedlings of the two subspecies originated from wild plants from the natural habitats in Sicily and cultivated in the Botanical Garden of Rome. Leaf morphological and physiological traits and growth dynamic were analyzed as well as the response to an imposed water stress experiment. The results underlined a higher relative growth rate in plant height $\left(\mathrm{RGR}_{\mathrm{H}}, \mathrm{cm} \cdot \mathrm{cm}^{-1} \cdot \mathrm{d}^{-1}\right)$ in $B$. rupestris subsp. rupestris also attested by the highest plant height $(\mathrm{H}, \mathrm{cm})$, leaf area $\left(\mathrm{LA}, \mathrm{cm}^{2}\right)$, specific leaf area (SLA $\left.\mathrm{cm} \cdot \mathrm{g}^{-1}\right)$, total leaf area per plant (TLA, $\left.\mathrm{cm}^{2}\right)$ and total plant dry mass (PDM, g plant $\left.{ }^{-1}\right)$. Moreover, the significantly highest net photosynthetic rates $\left(A, \mu \mathrm{mol} \mathrm{CO}_{2} \mathrm{~m}^{-2} \cdot \mathrm{s}^{-1}\right)$ during the study period of this subspecies was related to the high Chlorophyll content (Chl, SPAD units). B. rupestris subsp. rupestris was also the most tolerant subspecies to imposed water stress showing the highest relative water content (RWC, \%), $A$ and water use efficiency (WUE, $\mu \mathrm{mol} \cdot \mathrm{mmol}^{-1}$ ). On the whole, the results underline significant differences in plant and leaf traits of two subspecies allowing us to hypothesize that $B$. rupestris subsp. rupestris might be at a competitive advantage with respect to the hypothesized increase of air temperature and decrease of water availability in the Mediterranean Basin.
\end{abstract}

Keywords: Brassica rupestris Raf. subsp. hispida Raimondo \& Mazzola; Brassica rupestris Raf. subsp. rupestris; Conservation; Drought Stress; Endemism; Global Change; Growth Analysis; Physiological Traits; Red-Listed Species

\section{Introduction}

The genus Brassica belongs to the family of Brassicaceae that is characterized by 435 genera and 3675 species worldwide [1]. This genus is remarkably known for having more important agricultural and horticultural crops than any other genus; in addition to the cultivated species, many of the wild species grow as weeds, especially in North America, South America and Australia [1].

Sicily is one of the main centres of diversification for wild species belonging to the same cytodeme of Brassica oleracea L. [2-4]. In particular, the section Brassica of the genus Brassica growing in Sicily and in the small surrounding islands is represented by five distinct species $[2,4,5]$. Among these Brassica rupestris Raf. is endemic to North-West Sicily $[2,6]$.
On the basis of morphological characters, as well as ecological and geographical data, infraspecific taxa have been distinguished [2,7]. Subspecies, both geographically and morphologically distinct, were not found to be appreciably distant genetically, probably because of their recent evolution; molecular assay also detected a high level of polymorphism among the wild Sicilian populations [2]. In particular, Brassica rupestris Raf. subsp. hispida Raimondo \& Mazzola differs from Brassica rupestris Raf. subsp. rupestris by glaucous and more densely hairy leaves, and by the general smaller size [7]. B. rupestris subsp. hispida grows in a mountainous area in the South of Palermo (north-facing limestone cliff, from 800 to $1300 \mathrm{~m}$ a.s.l.) while B. rupestris subsp. rupestris has a wider distribution (limestone cliffs between sea level and $1100 \mathrm{~m}$ a.s.l.) and also grows in Stilo 
in Calabria [7]. Both subspecies are included in the Red List of the Italian Flora, respectively as endangered (EN) and low risk (LR) $[8,9]$. Their populations, in fact, are often restricted in size and distribution, basically because of the limited areas of cliffs, the competition with other species and the human disturbance (i.e. grazing, fire, quarries) [3]. Consequently, some of these populations need to be preserved by genetic resource conservation measures [10].

It has been estimated that species endemic to a single country represent $46 \%$ - $62 \%$ of world flora [11,12]. Rarity and endemism represent two factors which have particular significance when considering the risk of extincttion and decline, and species most prone to extinction currently are often considered to be those that are naturally rare [13]. Past extinctions, in fact, have been primarily concentrated within relatively small endemic-rich areas, and it is these regions that hold the key to current threat [13].

In this context, the goals of this work were to analyze the phenological and physiological responses of $B$. rupestris subsp. hispida and $B$. rupestris subsp. rupestris to environmental factors also in consideration of global change.

\section{Materials and Methods}

Experiments were carried out at the Botanical Garden of Rome ( $41^{\circ} 53^{\prime} 53^{\prime \prime} \mathrm{N}, 12^{\circ} 28^{\prime} 46^{\prime \prime} \mathrm{E}$; $53 \mathrm{~m}$ a.s.l., Latium) in the period April 2009 - December 2010. Plant material was obtained from the Germplasm Bank of Palermo Botanical Garden. Seeds of Brassica rupestris Raf. subsp. hispida Raimondo \& Mazzola and Brassica rupestris Raf. subsp. rupestris, collected respectively at Mt. Pizzuta ( $37^{\circ} 59^{\prime} 34^{\prime \prime} \mathrm{N}, 13^{\circ} 15^{\prime} 45^{\prime \prime} \mathrm{E} ; 1305 \mathrm{~m}$ a.s.l., Palermo, Sicily)

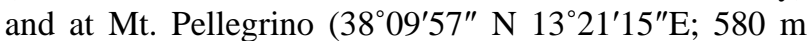
a.s.l., Palermo, Sicily), were sown in the middle of April 2009. Seedlings were grown in a glasshouse in $15 \mathrm{~cm}$ clay pots filled with peaty soil ( $\mathrm{pH} 4.5)$. Thirty days after sowing, fifty two-leaved seedlings of each subspecies were transplanted into clay pots $(24 \mathrm{~cm}$ in diameter and $32 \mathrm{~cm}$ in depth) filled with potting compost and placed under local environmental conditions.

\subsection{Climate}

Natural habitats of two subspecies were under a Mediterranean type of climate. The average annual air temperature of Mt. Pizzuta was $16.3^{\circ} \mathrm{C}$ and the average annual rainfall was $1130 \mathrm{~mm}$; the mean minimum air temperature of the coldest month (February) was $4.1^{\circ} \mathrm{C}$ and the mean maximum air temperature of the hottest month (August) was $33.1^{\circ} \mathrm{C}$ (Meteorological Stations of Piana

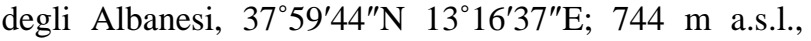
data for the period 1994-2003). Dry period was from
June to August (68.5 $\mathrm{mm}$ of total rainfall during that period). The average annual air temperature of Mt. Pellegrino was $19.6^{\circ} \mathrm{C}$ and the average annual rainfall was 562 $\mathrm{mm}$; the mean minimum air temperature of the coldest month (February) was $9.6^{\circ} \mathrm{C}$ and the mean maximum air temperature of the hottest month (August) was $31.3^{\circ} \mathrm{C}$ (Meteorological Stations of Palermo, Osservatorio Astonomico, $38^{\circ} 06^{\prime} 41^{\prime \prime} \mathrm{N} 13^{\circ} 21^{\prime} 13^{\prime \prime} \mathrm{E} ; 37 \mathrm{~m}$ a.s.l., data for the period 1994-2003). Dry period was from May to August (83.7 $\mathrm{mm}$ of total rainfall during that period).

The climate of Rome was of Mediterranean type, and most of the total annual rainfall $(698 \mathrm{~mm})$ occurred in autumn and winter (Meteorological Station of the Collegio Romano, $41^{\circ} 53^{\prime} 54^{\prime \prime} \mathrm{N} 12^{\circ} 28^{\prime} 466^{\prime \prime} \mathrm{E}$; $63 \mathrm{~m}$ a.s.l., data for the period 2000-2010). The mean minimum air temperature of the coldest month (January) was $4.8^{\circ} \mathrm{C}$, the mean maximum air temperature of the hottest months (July-August) was $31.0^{\circ} \mathrm{C}$ and the annual mean air temperature was $16.8^{\circ} \mathrm{C}$. Dry period was from June to August (59 $\mathrm{mm}$ of total rainfall during that period). During the study period, the mean maximum air temperature in July 2010 (the hottest month) was $32.6^{\circ} \mathrm{C}$ and in January (the coldest month) was $4.6^{\circ} \mathrm{C}$.

\subsection{Phenology and Growth Dynamic}

Phenological observations (time of seedling emergence, stem elongation, leafing) were carried out every three days, on 30 selected plants per subspecies, during the growing season.

Growth parameters included plant height $(\mathrm{H}, \mathrm{cm})$, leaf area $\left(\mathrm{LA}, \mathrm{cm}^{2}\right)$, specific leaf area (SLA, $\left.\mathrm{cm} \cdot \mathrm{g}^{-1}\right)$, total leaf area per plant (TLA, $\mathrm{cm}^{2}$ ), total plant dry mass $\left(\mathrm{PDM}, \mathrm{g} \cdot\right.$ plant $\left.^{-1}\right)$, relative growth rate in plant height $\left(\mathrm{RGR}_{\mathrm{H}}, \mathrm{cm} \cdot \mathrm{cm}^{-1} \cdot \mathrm{d}^{-1}\right)$, relative growth rate in plant dry mass $\left(R_{G R}, g \cdot g^{-1} \cdot d^{-1}\right)$ and plant growth efficiency (LE, $\left.\mathrm{m}^{3} \cdot \mathrm{g}^{-1}\right)$. LA measurements were carried out on leaf samples at the middle position of the stem (four leaves per plants), when its maximum surface was attained [14], using an area meter (Image Analysis System, Delta-T Devices, UK). SLA was calculated as LA to leaf dry mass (DM, g) after oven drying at $80^{\circ} \mathrm{C}$ to constant mass, according to [15]. $\mathrm{H}$ was measured until its maximum was attained. Ten plants per subspecies at maximum $\mathrm{H}$ were harvested and then separated into stem, leaves and roots. TLA was determined for all plants. Dry mass of each fraction was recorded after oven drying at $80^{\circ} \mathrm{C}$ to constant mass, and PDM was determined.

$\mathrm{RGR}_{\mathrm{H}}$ was calculated, according to [16], as $\mathrm{RGR}_{\mathrm{H}}=\ln$ $\mathrm{H}_{2}-\ln \mathrm{H}_{1} / \mathrm{t}_{2}-\mathrm{t}_{1}$, where $\mathrm{H}_{1}$ and $\mathrm{H}_{2}$ were plant height at time $t_{1}$ (seedling emergence) and $t_{2}$ (maximum plant height). $\mathrm{RGR}_{\mathrm{M}}$ was calculated, according to [17], as $\mathrm{RGR}_{\mathrm{m}}=\mathrm{ln}$ $\mathrm{PDM}_{2}-\ln \mathrm{PDM}_{1} / \mathrm{t}_{2}-\mathrm{t}_{1}$, where $\mathrm{PDM}_{1}$ and $\mathrm{PDM}_{2}$ were the total plant dry mass at time $t_{1}$ (emergence) and $t_{2}$ (maxi- 
mum total plant dry mass). The plant growth efficiency $\left(\mathrm{LE}, \mathrm{m}^{3} \cdot \mathrm{g}^{-1}\right)$ was calculated as $\mathrm{LE}=\Delta \mathrm{H} \times \mathrm{TLA} / \Delta \mathrm{PDM}$, where $\Delta \mathrm{H}$ and $\Delta \mathrm{PDM}$ were plant $\mathrm{H}$ growth increment and PDM increment, calculated over the growing season, according to $[18,19]$.

\subsection{Gas Exchange}

Gas exchange measurements were carried out monthly from May 2009 to May 2010. Net photosynthetic rates (A, $\left.\mu \mathrm{mol} \mathrm{CO} \mathrm{CO}^{-2} \cdot \mathrm{s}^{-1}\right)$, stomatal conductance $\left(g_{\mathrm{s}}, \mathrm{mol} \mathrm{H}_{2} \mathrm{O}\right.$ $\left.\mathrm{m}^{-2} \cdot \mathrm{s}^{-1}\right)$, transpiration rates $\left(E, \mathrm{mmol} \mathrm{H}_{2} \mathrm{O} \mathrm{m} \mathrm{m}^{-2} \cdot \mathrm{s}^{-1}\right)$ and photosynthetically active radiation (PAR, $\mu$ mol photon $\mathrm{m}^{-2} \cdot \mathrm{s}^{-1}$ ) were measured by an open infrared $\mathrm{CO}_{2}$ gas analyzer (ADC LCA4, UK), equipped with a leaf chamber (PLC, ADC, UK). Measurements were carried out on cloud-free days (PAR $>1000 \mu \mathrm{mol}$ photon $\mathrm{m}^{-2} \cdot \mathrm{s}^{-1}$ ), in the morning (from 9.30 to 12.30 ) to ensure that nearmaximum daily photosynthetic rates were measured [20]. On each sampling occasion, fully expanded leaves were used; the measurements were carried out on five plants per subspecies (three leaves per plant).

\subsection{Chlorophyll Content}

Total chlorophyll content (Chl, SPAD units) was measured seasonally by a SPAD-502 chlorophyll meter (Minolta, Japan), according to [21,22]. The measurements were carried out on fully expanded leaves after cleaning the surface dust. Measurements were carried out on five plants per subspecies (three leaves per plant) and three readings per leaf were averaged to account for withinleaf variations [23].

\subsection{Imposed Water Stress}

The water stress experiment was conducted in July 2010. Water was withheld from 10 plants per subspecies to generate water stress, according to [24]. The well-watered control plants (10 plants per subspecies) were watered regularly to field capacity. During the experiment, diurnal air temperature was $27.3^{\circ} \mathrm{C}$ and air humidity $59 \%$.

Water status, as expressed by predawn and midday leaf water potential $\left(\psi_{\mathrm{pd}}, \psi_{\mathrm{m}}\right)$, was measured on three fully expanded leaves per plant, before, during and after the water stress treatment. $\psi(\mathrm{MPa})$ was measured using a pressure chamber (SKPM 1400, Sky Instruments, UK). Predawn and midday leaf relative water content $\left(\mathrm{RWC}_{\mathrm{pd}}\right.$, $\mathrm{RWC}_{\mathrm{m}}$ ) were calculated at the same time, on three leaves per plant, as $(\mathrm{FM}-\mathrm{DM}) /(\mathrm{TM}-\mathrm{DM}) \times 100$ [25], where FM was the fresh leaf mass, DM the dry mass and TM the mass of fully hydrated samples. Leaf samples were hydrated until saturation for $48 \mathrm{~h}$ at $5^{\circ} \mathrm{C}$ in the dark and then dried in an oven at $80^{\circ} \mathrm{C}$ until constant mass. Gas exchange measurements $\left(A, g_{\mathrm{s}}, E\right)$ were monitored during the experiment on three fully expanded leaves per plant, in the morning. The instantaneous water use efficiency (WUE, $\mu \mathrm{mol} \cdot \mathrm{mmol}^{-1}$ ) was calculated as the ratio between $A$ and E, according to [26].

\subsection{Statistics}

Differences in the considered variables were determined by an analysis of variance (ANOVA). Simple regression analysis was carried out to examine the correlation between the considered physiological variables. All statistical tests were performed using a statistical software package (Statistica, Statsoft, USA).

\section{Results}

\subsection{Phenology and Growth Dynamic}

The phenological trend of $B$. rupestris subsp. hispida and $B$. rupestris subsp. rupestris was characterised by the seedling emergence at the end of April, respectively $12 \pm$ 1 days and $15 \pm 2$ days after sowing, when the daily mean air temperature was $15.8^{\circ} \mathrm{C} \pm 2.1^{\circ} \mathrm{C}$ and the mean minimum air temperature was $11.7^{\circ} \mathrm{C} \pm 1.6^{\circ} \mathrm{C}$.

The analyzed growth parameters are reported in Table 1. The maximum H $(20.3 \pm 1.1$ and $56.5 \pm 3.5 \mathrm{~cm}$, respectively for $B$. rupestris subsp. hispida and B. rupestris subsp. rupestris) was reached forty-three weeks after the beginning of the vegetative activity. The mean value of $\mathrm{RGR}_{\mathrm{H}}$ was $0.0175 \pm 0.0010 \mathrm{~cm} \cdot \mathrm{cm}^{-1} \cdot \mathrm{d}^{-1}$ for $B$. rupestris subsp. hispida and $0.0208 \pm 0.0020 \mathrm{~cm} \cdot \mathrm{cm}^{-1} \cdot \mathrm{d}^{-1}$ for $B$. rupestris subsp. rupestris. Leaves were produced con-

Table 1. Mean values ( \pm standard error) for the considered plant traits in Brassica rupestris subsp. hispida and Brassica rupestris subsp. rupestris. $\mathrm{H}$ = plant height; $\mathrm{LA}=$ leaf area; SLA = specific leaf area; TLA = total leaf area per plant; PDM = total plant dry mass; $\mathbf{R G R}_{\mathrm{H}}=$ relative growth rate in plant height; $\mathbf{R G R}_{\mathbf{M}}=$ relative growth rate in plant dry mass; $L E=$ plant growth efficiency. Mean values are significantly different (ANOVA, $p<0.01$ ).

\begin{tabular}{|c|c|c|}
\hline Growth parameters & $\begin{array}{l}\text { Brassica rupestris } \\
\text { subsp. hispida }\end{array}$ & $\begin{array}{l}\text { Brassica rupestris } \\
\text { subsp. rupestris }\end{array}$ \\
\hline $\mathrm{H}(\mathrm{cm})$ & $20.3 \pm 1.1$ & $56.5 \pm 3.5$ \\
\hline $\mathrm{LA}\left(\mathrm{cm}^{2}\right)$ & $77.1 \pm 12.0$ & $109.6 \pm 16.9$ \\
\hline $\operatorname{SLA}\left(\mathrm{cm}^{2} \cdot \mathrm{g}^{-1}\right)$ & $137.2 \pm 17.1$ & $164.3 \pm 15.1$ \\
\hline TLA $\left(\mathrm{cm}^{2}\right)$ & $1052.3 \pm 17.1$ & $1273.5 \pm 21.2$ \\
\hline PDM (g) & $3.3 \pm 0.7$ & $24.3 \pm 2.8$ \\
\hline $\mathrm{RGR}_{\mathrm{H}}\left(\mathrm{cm} \cdot \mathrm{cm}^{-1} \cdot \mathrm{d}^{-1}\right)$ & $0.0175 \pm 0.0010$ & $0.0208 \pm 0.0020$ \\
\hline $\operatorname{RGR}_{M}\left(g \cdot g^{-1} \cdot d^{-1}\right)$ & $0.0160 \pm 0.0008$ & $0.0181 \pm 0.0010$ \\
\hline $\operatorname{LE}\left(\mathrm{m}^{3} \cdot \mathrm{g}^{-1}\right)$ & $0.00161 \pm 0.00010$ & $0.00295 \pm 0.00030$ \\
\hline
\end{tabular}


tinuously during the year from the middle of May, and at full expansion SLA was significantly different in the subspecies $\left(137.2 \pm 17.1\right.$ and $164.3 \pm 15.1 \mathrm{~cm}^{2} \cdot \mathrm{g}^{-1}$, respectively for $B$. rupestris subsp. hispida and $B$. rupestris subsp. rupestris). At the end of the vegetative period, TLA, PDM, RGR ${ }_{M}$, and LE were significantly higher for $B$. rupestris subsp. rupestris.

\subsection{Gas Exchange}

During the study period, B. rupestris subsp. rupestris showed significantly higher values of measured gas exchange parameters than $B$. rupestris subsp. hispida (Figure 1). The highest $A(26.7 \pm 0.5$ and $33.7 \pm 0.4 \mu \mathrm{mol}$ $\mathrm{CO}_{2} \mathrm{~m}^{-2} \cdot \mathrm{s}^{-1}$, respectively for $B$. rupestris subsp. hispida and $B$. rupestris subsp. rupestris; an average of the two years) was measured in May, when the daily mean air temperature was $19.6^{\circ} \mathrm{C} \pm 1.3^{\circ} \mathrm{C}$, decreasing by $50 \%$ in August $\left(31.1^{\circ} \mathrm{C} \pm 1.8^{\circ} \mathrm{C}\right.$ mean maximum air temperature), and by $70 \%$ in January $\left(4.4^{\circ} \mathrm{C} \pm 1.5^{\circ} \mathrm{C}\right.$ mean air temperature) (Figure 1). $g_{\mathrm{s}}$ and $E$ showed the highest values in spring and summer and the lowest ones in winter (Figure 1). There were significant correlations between
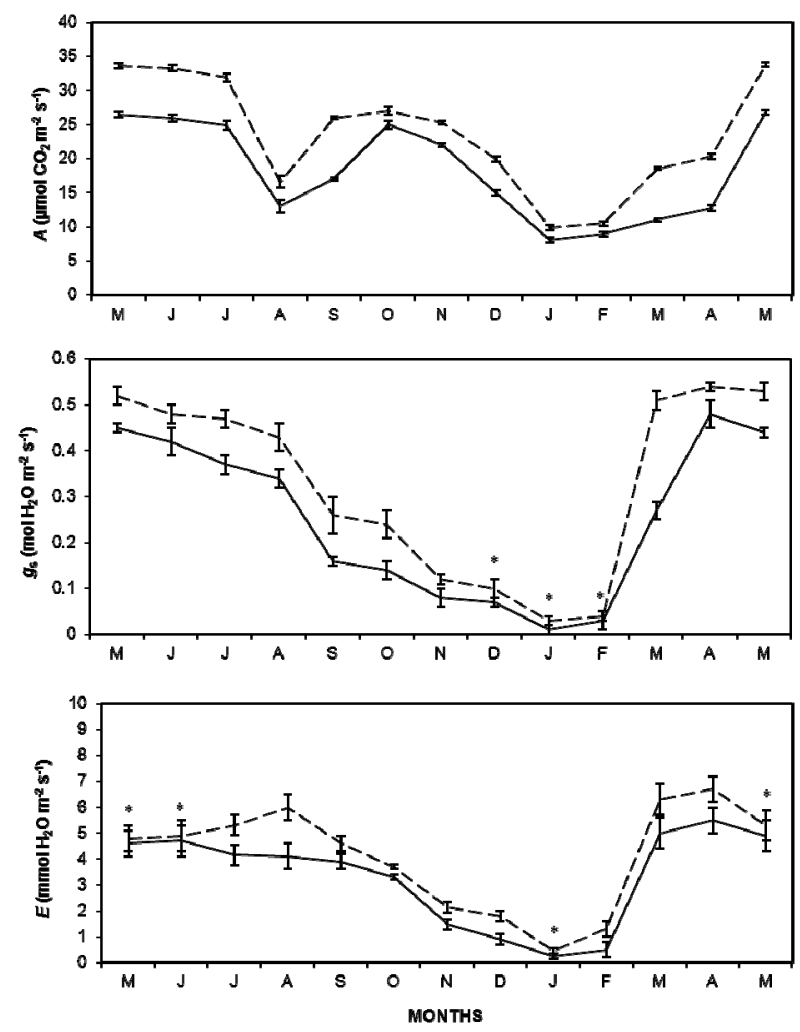

Figure 1. Monthly trend of net photosynthetic rates $(A)$, stomatal conductance $\left(g_{\mathrm{s}}\right)$ and transpiration rates $(E)$ of Brassica rupestris subsp. hispida (continuous line) and Brassica rupestris subsp. rupestris (dotted line). Standard error is shown. Mean values are significantly different (ANOVA, $p<0.01$ ), except values with ${ }^{*}$. $g_{\mathrm{s}}$ and $A$ (Figure 2).

\subsection{Chlorophyll Content}

B. rupestris subsp. rupestris showed significantly higher values of Chl than B. rupestris subsp. hispida (Figure 3). The highest Chl was found in spring (51.1 \pm 1.2 and 43.9 \pm 1.6 SPAD units respectively) and autumn (50.8 \pm 1.9 and $43.8 \pm 1.7$ SPAD units respectively), decreasing in summer by $2 \%$ in $B$. rupestris subsp. hispida and $7 \%$ in $B$. rupestris subsp. rupestris and by $2.6 \%$ and $12 \%$, respectively in winter. There were significant correlations between Chl and $A$ (Figure 2).

\subsection{Imposed Water Stress}

In the control plants, predawn and midday RWC and $\psi$ were constant during the experimental period, and differrences between subspecies were not significant (Table 2; Figure 4). Stressed plants showed a progressive reducetion of RWC and $\psi$ and a higher reduction was observed after 4 days of water stress, when differences between subspecies were significant (Table 2; Figure 4). The reduction of RWC and $\psi$ was greater in $B$. rupestris subsp. hispida $(53.7 \% \pm 1.0 \%$ and $-4.04 \mathrm{MPa}$, at midday) compared with $B$. rupestris subsp. rupestris $(61.3 \% \pm$ $1.2 \%$ and $-3.58 \mathrm{MPa}$, at midday). Upon re-watering, the plant water status returned to that of the prior water stress after 1 day.

In both subspecies, the drought-induced decline in RWC and water potential was accompanied by large reductions in gas exchange (Figure 5). Differences be tween subspecies were significant and after 4 days of water stress, $B$. rupestris subsp. hispida showed lower

Table 2. Predawn $\left(\mathrm{RWC}_{\mathrm{pd}}\right)$ and midday $\left(\mathrm{RWC}_{\mathrm{m}}\right)$ leaf relative water content measured at the beginning (start day), at the end (maximum stress day) and after re-watering, in control and stressed plants of Brassica rupestris subsp. hispida (H) and Brassica rupestris subsp. rupestris (R). Mean values ( \pm standard error) are shown. ${ }^{*}=$ mean values are significantly different (ANOVA, $p<0.01$ ).

\begin{tabular}{ccccc}
\hline & control & \multicolumn{3}{c}{ stress } \\
\hline RWC $_{\mathrm{pd}}(\%)$ & $\mathrm{H}$ & $\mathrm{R}$ & $\mathrm{H}$ & $\mathrm{R}$ \\
start day 0 & $94.8 \pm 3.4$ & $95.4 \pm 2.2$ & $95.2 \pm 3.1$ & $96.1 \pm 2.5$
\end{tabular}

maximum stress day $494.5 \pm 2.694 .6 \pm 3.758 .4 \pm 2.9^{*} \quad 64.8 \pm 2.2^{*}$

recovery day $1 \quad 94.3 \pm 3.694 .9 \pm 2.894 .8 \pm 2.3 \quad 95.7 \pm 1.9$

$\begin{array}{ccccc}\mathrm{RWC}_{\mathrm{m}}(\%) & \mathrm{H} & \mathrm{R} & \mathrm{H} & \mathrm{R} \\ \text { start day 0 } & 92.2 \pm 1.9 & 93.2 \pm 1.4 & 93.1 \pm 1.3 & 92.7 \pm 1.6\end{array}$

maximum stress day $489.9 \pm 1.591 .0 \pm 1.153 .7 \pm 1.0^{*} 61.3 \pm 1.2^{*}$

recovery day $1 \quad 91.4 \pm 2.193 .3 \pm 1.792 .6 \pm 1.9 \quad 91.3 \pm 1.3$ 

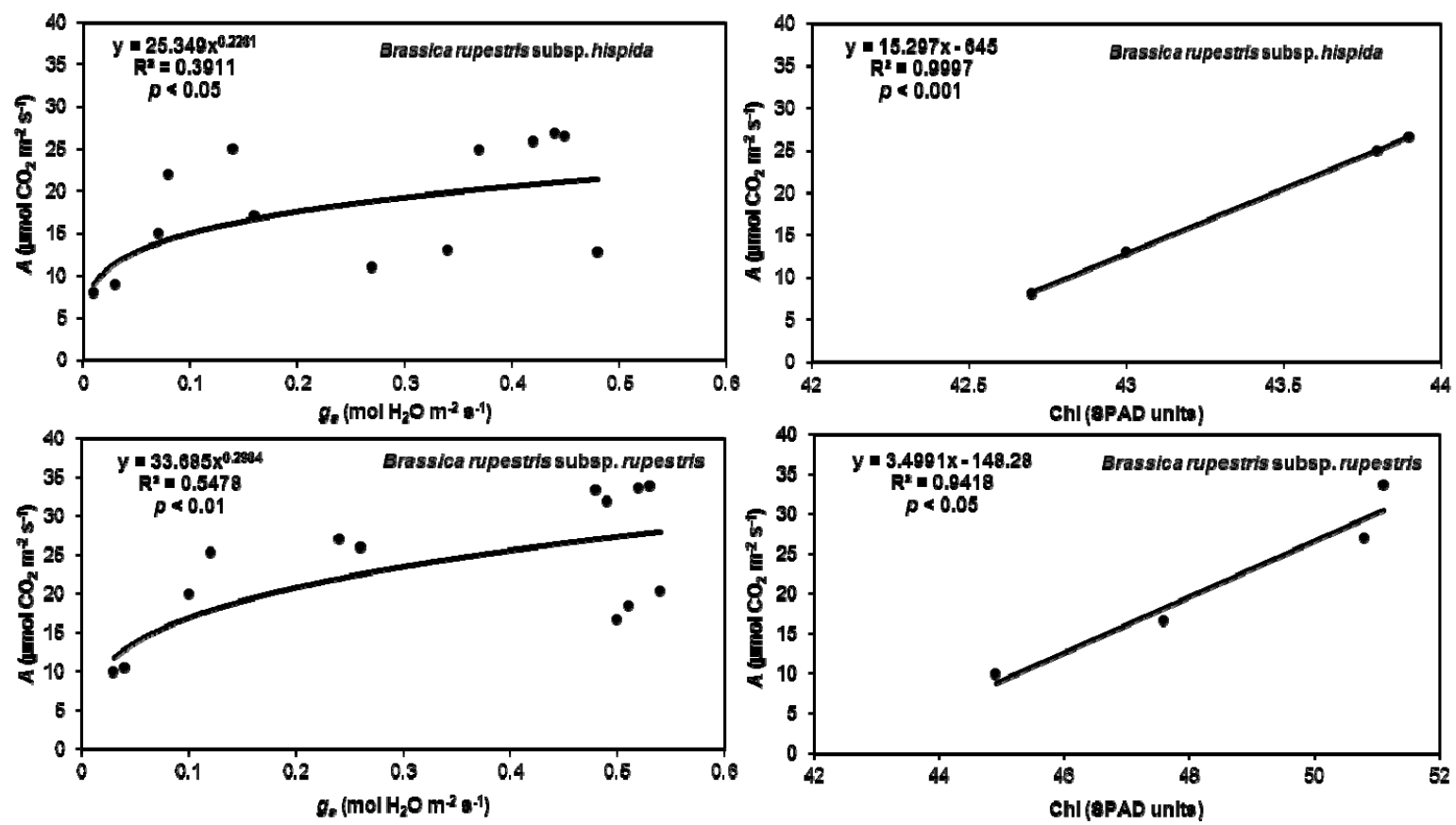

Figure 2. Regression analysis between the considered physiological variables for Brassica rupestris subsp. hispida and Brassica rupestris subsp. rupestris. $A=$ net photosynthetic rates; $g_{\mathrm{s}}=$ stomatal conductance; $\mathrm{Chl}=$ Chlorophyll content. Regression equation, determination's coefficient $\left(R^{2}\right)$ and $p$ level are shown.

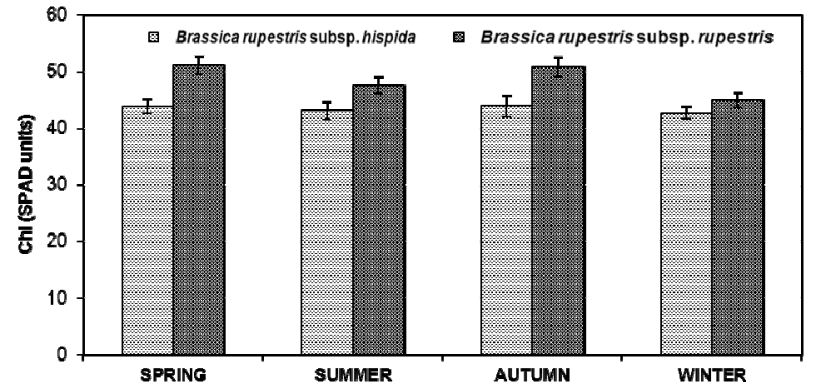

Figure 3. Seasonal trend of chlorophyll content (Chl) of Brassica rupestris subsp. hispida and Brassica rupestris subsp. rupestris. Standard error is shown. Mean values are significantly different (ANOVA, $p<0.05$ ).

values of $A, g_{\mathrm{s}}$ and WUE. Upon re-watering, in addition to the plant water status, the gas exchange returned to that of prior to water stress after 1 day.

\section{Discussion}

The geographical distribution of species can be perceived as a result of underlying multiple factors varying in space and time [27]. It is widely considered that the occurrence of species in a given locality is constrained by climatic processes on broad spatial scales [28], whereas the availability of appropriate habitat determines distribution patterns on local scales [29,30].

The Mediterranean climate is characterised by a hot dry period in summer and a cool wet period in winter

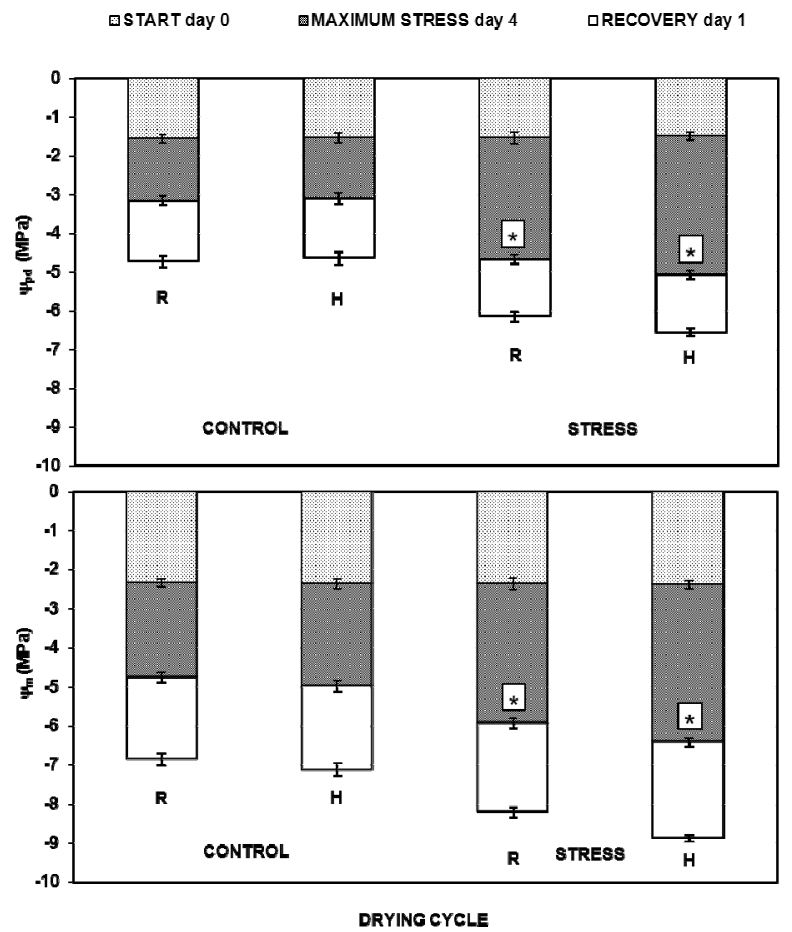

Figure 4. Predawn $\left(\psi_{\mathrm{pd}}\right)$ and midday $\left(\psi_{\mathrm{m}}\right)$ leaf water potential measured at the beginning (start day), at the end (maximum stress day) and after re-watering, in control and stressed plants of Brassica rupestris subsp. hispida $(\mathrm{H})$ and Brassica rupestris subsp. rupestris (R). Mean values ( \pm standard error) are shown. ${ }^{*}=$ mean values are significantly different (ANOVA, $p<0.01$ ). 

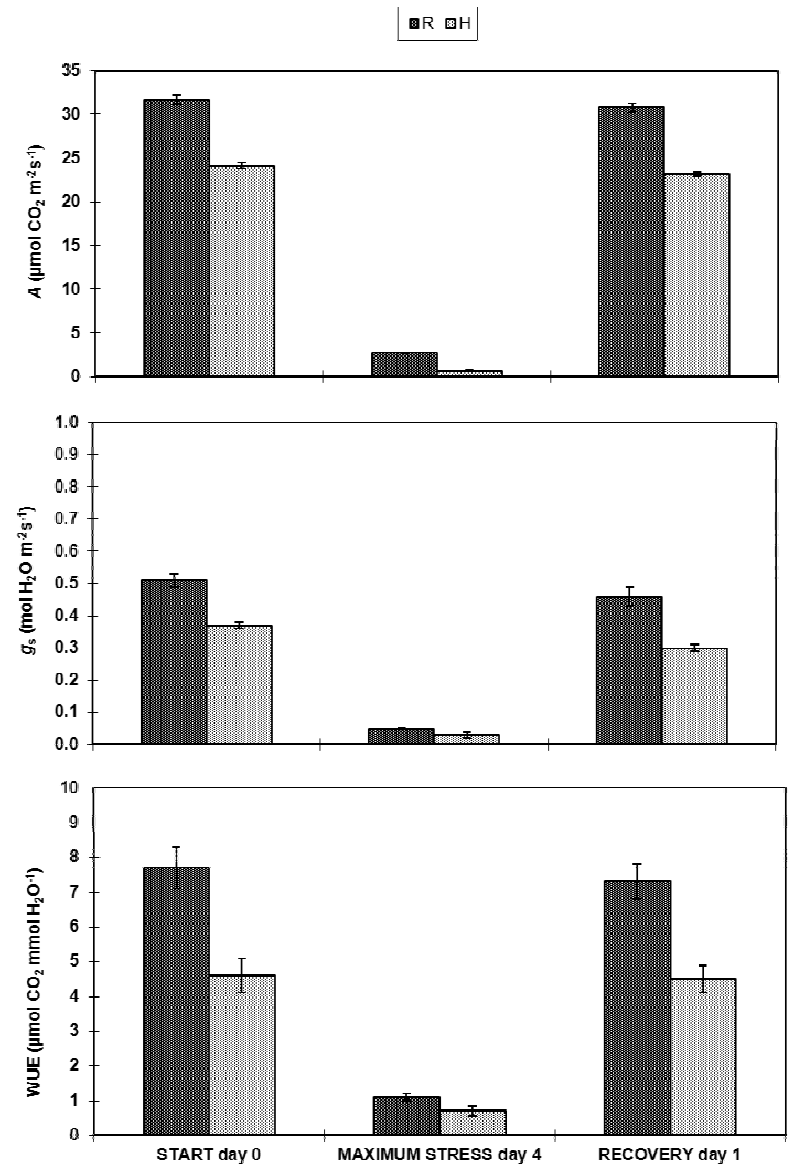

Figure 5. Trend of net photosynthetic rates $(A)$, stomatal conductance $\left(g_{s}\right)$ and water use efficiency (WUE) of Brassica rupestris subsp. hispida $(\mathrm{H})$ and Brassica rupestris subsp. rupestris $(\mathrm{R})$ measured at the beginning (start day), at the end (maximum stress day) and after re-watering, in stressed plants. Mean values are significantly different (ANOVA, $p<$ 0.05).

[31,32]. In particular, the effects of water deficits during the summer severely influence the distribution and composition of vegetation in the Mediterranean Basin [33-35] and water availability in this area is likely to be reduced in the near future by the predicted increases in temperatures, and the consequent increases of evapotranspiration rates [34,36,37].

Projections of increased temperatures and more frequent drought events question the persistence of many plant species in their current distributions [38-40]. Among the different species, different morphological, physiological and phenological responses are expected under the new climatic conditions [31,34,41]. Plant growth, in particular, is largely limited by the length of the growing season [42], and temperature is one of the most important environmental factors for vegetative activity [31,32,34, 43-46]. In Mediterranean climates, the length of the growing season is constrained to a short period in spring and early summer [32,34]. Therefore, a rapid deployment of leaf area and a high photosynthetic capacity during this period might have important positive effects on the final carbon balance of the leaf population [47].

On the whole, the results underline significant differences in plant and leaf trait responses of $B$. rupestris subsp. rupestris and $B$. rupestris subsp. hispida to environmental factors. Seedling emergence of two subspecies happened at the end of April, when the daily mean air temperature was $15.8^{\circ} \mathrm{C} \pm 2.1^{\circ} \mathrm{C}$, and maximum $\mathrm{H}$ was reached in the middle of June, when the daily mean air temperature was $23.9^{\circ} \mathrm{C} \pm 1.8^{\circ} \mathrm{C}$. Since plant size is an important determinant of survival and reproduction in nature, differences in RGR are of central importance in plant ecology [48]. The mean $\mathrm{RGR}_{\mathrm{H}}$ and $\mathrm{RGR}_{\mathrm{M}}$ were both highest in $B$. rupestris subsp. rupestris in respect to $B$. rupestris subsp. hispida, and at the end of the growing season the two subspecies showed wide variations in their growth parameters. In particular, higher TLA of $B$. rupestris subsp. rupestris (1273.5 $\pm 21.2 \mathrm{~cm}^{2}$ compared to $1052.3 \pm 17.1 \mathrm{~cm}^{2}$ of $B$. rupestris subsp. hispida) maximised light interception resulting in higher biomass accumulation $\left(24.3 \pm 2.8 \mathrm{~g} \mathrm{plant}^{-1}\right.$ respect to $3.3 \pm 0.7 \mathrm{~g}$ plant $^{-1}$ of $B$. rupestris subsp. hispida), according to the results obtained for other species [32,49-51].

SLA is an important plant functional trait as it is an indicator of ecophysiological characteristics like relative growth rate, stress tolerance and leaf longevity [15]. [52] underline that SLA is one of the major contributors to an axis of resource capture, usage and availability and it appears as a trait with more direct ecological interpretation in comparative studies [53]. Higher SLA is beneficial for obtaining a more extensive foliage display that captures more light for constant biomass investment [54]. Among the studied subspecies, the highest SLA was found in $B$. rupestris subsp. rupestris, confirming that fast-growing species (i.e. higher RGR) show high SLA [53].

According to [22], in this study photosynthetic pigments should be related to SLA and leaf type. The pubescent leaves of $B$. rupestris subsp. hispida have, during the year, a lower Chl than the glabrous leaves of $B$. rupestris subsp. rupestris. These differences may arise because the pubescence may serve to change the spectral quality of incoming radiation as well as reflecting a proportion of it, thereby minimizing harm to the photosynthetic apparatus $[22,55,56]$. Variation in pigment concentration and light-harvesting capacity has been linked with differences in overall photosynthetic capacity [57,58]. During the study period, $B$. rupestris subsp. rupestris showed significantly higher $A$ values than $B$. rupestris subsp. hispida, reaching the maximum values $(33.7 \pm 0.4$ $\mu \mathrm{mol} \mathrm{CO}_{2} \mathrm{~m}^{-2} \cdot \mathrm{s}^{-1}$ compared to $26.7 \pm 0.5$ of $B$. rupestris 
subsp. hispida) in May, when the daily mean air temperature was $19.6 \pm 1.3$.

Photosynthesis in plants is closely related to plant water potential [59]. Decreasing water status in plants is commonly linked to decreased photosynthesis and decreased production [60,61]. Under drought, $\psi$ and RWC of $B$. rupestris subsp. rupestris were higher than $B$. rupestris subsp. hispida, which appears to be the most susceptible to soil moisture limitations, as was expected based on its distribution in areas with high year-round soil moisture levels [62-64]. Similarly, B. rupestris subsp. rupestris was able to maintain higher $A$, higher $g_{\mathrm{s}}$ and higher WUE in water stress. In particular, higher WUE is expected to be the favorable trait in water-limited environments, where water loss is minimized [65-68].

In conclusion, the results allow us to hypothesize that B. rupestris subsp. rupestris might be at a competitive advantage with respect to the increase of air temperature and drought stress. Ecological requirements and mobility affect the scale on which species respond to their environment [30]. Knowing the potential growth of red-listed species and their resource use capability is aimed in facilitating efficient allocation of management efforts to critical regions with high conservation value [14].

\section{Acknowledgements}

This paper was supported by the grants PRIN 2007 (Research Projects of Relevant National Interest) "Italian threatened wild flora: ex situ conservation and characterization by morphoanatomical, ecophysiological and genetic analyses" co-financed by MIUR (Italian Ministry of University and Research). We wish to thank you to the Germplasm Banks of Palermo University who supplied the seeds for this research.

\section{REFERENCES}

[1] R. S. Purty, G. Kumar, S. L. Singla-Pareek and A. Pareek, "Towards Salinity Tolerance in Brassica: An Overview," Physiology and Molecular Biology of Plants, Vol. 14, No. 1-2, 2008, pp. 39-49. doi:10.1007/s12298-008-0004-4

[2] A. Geraci, I. Divaret, F. M. Raimondo and A. M. Chèvre, "Genetic Relationships between Sicilian Wild Populations of Brassica Analysed with RAPD Markers,” Plant Breeding, Vol. 120, No. 3, 2001, pp. 193-196. doi:10.1046/j.1439-0523.2001.00589.x

[3] A. Geraci, A. M. Chèvre, I. Divaret, F. Eber and F. M. Raimondo, "Isozyme Analysis of Genetic Diversity in Wild Sicilian Populations of Brassica Sect. Brassica in View of Genetic Resources Management," Genetic Resources and Crop Evolution, Vol. 51, No. 2, 2004, pp. 137-146. doi:10.1023/B:GRES.0000020855.61542.ef

[4] J. Mei, Q. Li, X. Yang, L. Qian, L. Liu, J. Yin, M. Frauen, J. Li and W. Qian, "Genomic Relationships between Wild and Cultivated Brassica oleracea L. with Emphasis on the Origination of Cultivated Crops," Genetic Resources and Crop Evolution, Vol. 57, No. 5, 2010, pp. 687-692. doi:10.1007/s10722-009-9504-5

[5] S. Snogerup, M. Gustafsson and R. von Bothmer, "Brassica sect. Brassica (Brassicaceae). I Taxonomy and Variation,” Willdenowia, Vol. 19, No. 2, 1990, pp. 271-365.

[6] F. M. Raimondo, P. Mazzola and D. Ottonello, "On the Taxonomy and Distribution of Brassica sect. Brassica (Cruciferae) in Sicily,” Flora Mediterranea, Vol. 1, No. 1, 1991, pp. 63-86.

[7] F. M. Raimondo and P. Mazzola, “A New Taxonomic Arrangement in the Sicilian Members of Brassica L. sect. Brassica,” Lagascalia, Vol. 19, No. 1-2, 1997, pp. 831838.

[8] F. Conti, A. Manzi and F. Pedrotti, "Liste Rosse Regionali delle Piante d’Italia,” TIPAR, Roma, 1997.

[9] F. Conti, G. Abbate, A. Alessandrini and C. Blasi, "An Annotated Checklist of the Italian Vascular Flora,” Palombi Editori, Roma, 2005.

[10] F. M. Raimondo, L. Gianguzzi and V. Ilardi, "Inventario delle Specie a Rischio Nella Flora Vascolare Nativa Della Sicilia," Quaderni di Botanica Ambientale e Applicata, Vol. 3, No. 1, 1994, pp. 65-132.

[11] N. C. A. Pitman and P. M. Jørgensen, "Estimating the Size of the World's Threatened Flora," Science, Vol. 298, No. 5595, 2002, pp. 989-989. doi:10.1126/science.298.5595.989

[12] K. M. Robbirt, D. L. Roberts and J. A. Hawkins, “Comparing IUCN and Probabilistic Assessments of Threat: Do IUCN Red List Criteria Conflate Rarity and Threat?" Biodiversity and Conservation, Vol. 15, No. 6, 2006, pp. 1903-1912. doi:10.1007/s10531-005-4307-2

[13] S. L. Pimm, “Extinction,” In: W. J. Sutherland, Ed., Conservation Science and Action, Blackwell Science, Ltd., Oxford, 1998, pp. 20-38. doi:10.1002/9781444313499.ch2

[14] L. Gratani, M. F. Crescente, G. Fabrini and L. Varone, "Growth Pattern of Bidens cernua L.: Relationships between RGR and Its Physiological and Morphological Components,” Photosynthetica, Vol. 46, No. 2, 2008, pp. 179-184. doi:10.1007/s11099-008-0029-5

[15] J. F. Scheepens, E. S. Frei and J. Stöcklin, "Genotypic and Environmental Variation in Specific Leaf Area in a Widespread Alpine Plant after Transplantation to Different Altitudes,” Oecologia, Vol. 164, No. 1, 2010, pp. 141150. doi:10.1007/s00442-010-1650-0

[16] E. H. DeLucia, T. W. Sipe, J. Herrick and H. Maherali, "Sapling Biomass Allocation and Growth in the Understory of a Deciduous Hardwood Forest," American Journal of Botany, Vol. 85, No. 7, 1998, pp. 955-963. doi:10.2307/2446362

[17] G. C. Evans, "The Quantitative Analysis of Plant Growth,” Blackwell, Oxford, 1972.

[18] D. A. King, "Influence of Light Level on the Growth and Morphology of Saplings in a Panamanian Forest," American Journal of Botany, Vol. 81, No. 8, 1994, pp. 948-957. 


\section{doi:10.2307/2445287}

[19] D. A. King, "Branch Growth and Biomass Allocation in Abies amabilis Saplings in Contrasting Light Environments,” Tree Physiology, Vol. 17, No. 4, 1997, pp. 251258. doi:10.1093/treephys/17.4.251

[20] P. B. Reich, B. D. Kloeppel, D. S. Ellsworth and M. B. Walters, "Different Photosynthesis-Nitrogen Relations in Deciduous Hardwood and Evergreen Coniferous Tree Species,” Oecologia, Vol. 104, No. 1, 1995, pp. 24-30.

[21] R. D. Marquard and J. L. Tipton, "Relationship between Extractable Chlorophyll and an in Situ Method to Estimate Leaf Greenness,” Hortscience, Vol. 22, No. 6, 1987, p. 1327.

[22] R. E. Martin, P. Gregory and L. S. Asner, "Genetic Variation in Leaf Pigment, Optical and Photosynthetic Function among Diverse Phenotypes of Metrosideros polymorpha Grown in a Common Garden,” Oecologia, Vol. 151, No. 3, 2007, pp. 387-400. doi:10.1007/s00442-006-0604-z

[23] V. O. Sadras, L. Echarte and F. H. Andrade, "Profiles of Leaf Senescence during Reproductive Growth of Sunflower and Maize,” Annals of Botany, Vol. 85, No. 2, 2000, pp. 187-195. doi:10.1006/anbo.1999.1013

[24] P. Pesoli, L. Gratani and W. Larcher, "Responses of Quercus ilex from Different Provenances to Experimentally Imposed Water Stress,” Biologia Plantarum, Vol. 46, No. 4, 2003, pp. 577-581. doi:10.1023/A:1024823830225

[25] M. A. Lo Gullo and S. Salleo, "Different Strategies of Drought Resistance in Three Mediterranean sclerophyllous Trees Growing in the Same Environmental Conditions,” New Phytologist, Vol. 108, No. 3, 1988, pp. 267276. doi:10.1111/j.1469-8137.1988.tb04162.x

[26] W. Larcher, "Physiological Plant Ecology,” Springer, Berlin, 2003. doi:10.1007/978-3-662-05214-3

[27] M. A. Huston, "Biological Diversity: The Coexistence of Species on Changing Landscapes," Cambridge University Press, Cambridge, 1994.

[28] D. J. Currie, "Energy and Large-Scale Patterns of Animal- and Plant-Species Richness," American Naturalist, Vol. 137, No. 1, 1991, pp. 27-49.

[29] R. G. Pearson, T. P. Dawson and C. Liu, "Modelling Species Distributions in Britain: A Hierarchical Integration of Climate and Land-Cover Data," Ecography, Vol. 27, No. 3, 2004, pp. 285-298. doi:10.1111/j.0906-7590.2004.03740.x

[30] S. Kivinen, M. Luoto, R. K. Heikkinen, K. Saarinen and T. Ryttäri, "Threat Spots and Environmental Determinants of Red-Listed Plant, Butterfly and Bird Species In Boreal Agricultural Environments,” Biodiversity and Conservation, Vol. 17, No. 13, 2008, pp. 3289-3305. doi:10.1007/s10531-008-9429-X

[31] L. Gratani, P. Pesoli, M. F. Crescente, K. Aichner and W. Larcher, "Photosynthesis as a Temperature Indicator in Quercus ilex L.," Global and Planetary Change, Vol. 24, No. 2, 2000, pp. 153-163.

[32] M. F. Crescente, L. Gratani and W. Larcher, "Shoot Growth
Efficiency and Production of Quercus ilex L. in Different Climates,” Flora, Vol. 197, No. 1, 2002, pp. 2-9. doi:10.1078/0367-2530-00007

[33] C. P. Osborne, P. L. Mitchell, J. E. Sheehy and F. I. Woodward, "Modelling the Recent Historical Impacts of Atmospheric $\mathrm{CO}_{2}$ Climate Change on Mediterranean Vegetation,” Global Change Biology, Vol. 6, No. 4, 2000, pp. 445-458. doi:10.1046/j.1365-2486.2000.00336.x

[34] L. Gratani, M. Meneghini, P. Pesoli and M. F. Crescente, "Structural and Functional Plasticity of Quercus ilex Seedlings of Different Provenances in Italy," Trees-Structure and Function, Vol. 17, No. 6, 2003, pp. 515-521. doi:10.1007/s00468-003-0269-8

[35] J. Flexas, J. Galmés, M. Ribas-Carbó and H. Medrano, “The Effects of Drought in Plant Respiration," Advances in Photosynthesis and Respiration, Vol. 18, 2005, pp. 85-94. doi:10.1007/1-4020-3589-6_6

[36] J. Piñol, J. Terradas and F. Lloret, "Climate Warming, Wildfire Hazard, and Wildfire Occurrence in Coastal Eastern Spain,” Climatic Change, Vol. 38, No. 3, 1998, pp. 345-357. doi:10.1023/A:1005316632105

[37] R. Ogaya and J. Peñuelas, “Contrasting Foliar Responses to Drought in Quercus ilex and Phillyrea latifolia," Biologia Plantarum, Vol. 50, No. 3, 2006, pp. 373-382. doi:10.1007/s10535-006-0052-y

[38] IPCC, "Climate Change 2007: The Physical Science Basis. Contribution of Working Group I to the Fourth Assessment Report of the Intergovernmental Panel on Climate Change," Cambridge University Press, Cambridge, 2007.

[39] S. Richter, T. Kipfer, T. Wohlgemuth, C. Calderón Guerrero, J. Ghazoul and B. Moser, "Phenotypic Plasticity Facilitates Resistance to Climate Change in a Highly Variable Environment," Oecologia, Vol. 169, No. 1, 2012, pp. 269-279. doi:10.1007/s00442-011-2191-x

[40] A. B. Moyes, C. Castanha, M. J. Germino and L. M. Kueppers, "Warming and the Dependence of Limber Pine (Pinus flexilis) Establishment on Summer Soil Moisture within and above Its Current Elevation Range,” Oecologia, Vol. 171, No. 1, 2013, pp. 271-282. doi:10.1007/s00442-012-2410-0

[41] R. Ogaya and J. Peñuelas, “Contrasting Foliar Responses to Drought in Quercus ilex and Phillyrea latifolia," Biologia Plantarum, Vol. 50, No. 3, 2006, pp. 373-382. doi:10.1007/s10535-006-0052-y

[42] K. Kikuzawa, "The Basis for Variation in Leaf Longevity of Plants,” Vegetatio, Vol. 121, No. 1-2, 1995, pp. 89-100. doi:10.1007/BF00044675

[43] L. Gratani and M. F. Crescente, "Phenology and Leaf Adaptive Strategies of Mediterranean Maquis Plants," Ecologia Mediterranea, Vol. 23, No. 3-4, 1997, pp. 1119.

[44] M. Fenner, "The Phenology of Growth and Reproduction in Plants,” Perspectives in Plant Ecology Evolution and Systematics, Vol. 1, No. 1, 1998, pp. 78-91. doi:10.1078/1433-8319-00053

[45] C. Parmesan, "Influences of Species, Latitudes and Methodologies on Estimates of Phenological Response to Glo- 
bal Warming," Global Change Biology, Vol. 13, No. 9, 2007, pp. 1860-1872. doi:10.1111/j.1365-2486.2007.01404.x

[46] J. E. Nedlo, T. A. Martin and J. M. Vose, "Growing Season Temperatures Limit Growth of Loblolly Pine (Pinus taeda L.) Seedlings across a Wide Geographic Transect,” Trees-Structure and Function, Vol. 23, No. 4, 2009, pp. 751-759. doi:10.1007/s00468-009-0317-0

[47] S. Mediavilla and A. Escudero, "Relative Growth Rate of Leaf Biomass and Leaf Nitrogen Content in Several Mediterranean Woody Species,” Plant Ecology, Vol. 168, No. 2, 2003, pp. 321-332. doi:10.1023/A:1024496717918

[48] B. Shipley, "Trade-Offs between Net Assimilation Rate and Specific Leaf Area in Determining Relative Growth Rate: Relationship with Daily Irradiance,” Functional Ecology, Vol. 16, No. 5, 2002, pp. 682-689. doi:10.1046/j.1365-2435.2002.00672.x

[49] P. Dijkstra and H. Lambers, "Photosynthesis and Respiration of Two Inbred Lines of Plantago Major L. Differing in Relative Growth Rate,” In: R. Marcelle, H. Clijsters and M. Van Poucke, Eds., Biological Control of Photosynthesis, Martinus Nijhoff Publishers, The Hague, 1986, pp. 251-255. doi:10.1007/978-94-009-4384-1_23

[50] E. Roetman and A. A. Sterk, "Growth of Micro Species of Different Sections of Taraxacum in Climatic Chambers,” Acta Botanica Neerlandica, Vol. 35, No. 1, 1986, pp. 5- 22.

[51] H. Poorter and C. Remkes, "Leaf Area Ratio and Net Assimilation Rate of 24 Wild Species Differing in Relative Growth Rate,” Oecologia, Vol. 83, No. 4, 1990, pp. 553559.

[52] J. P. Grime, K. Thompson, R. Hunt, J. G. Hodgson, J. H. C. Cornelissen, I. H. Rorison, G. A. F. Hendry, T. W. Ashenden, A. P. Askew, S. R. Band, R. E. Booth, C. C. Bossard, B. D. Campbell, J. E. L. Cooper, A. W. Davison, P. L. Gupta, W. Hall, D. W. Hand, M. A. Hannah, S. H. Hillier, D. J. Hodkinson, A. Jalili, Z. Liu, J. M. L. Mackey, N. Matthews, M. A. Mowforth, A. M. Neal, R. J. Reader, K. Reiling, W. Ross-Fraser, R. E. Spencer, F. Sutton, D. E. Tasker, P. C. Thorpe and J. Whitehouse, "Integrated Screening Validates Primary Axes of Specialisation in Plants,” Oikos, Vol. 79, No. 2, 1997, pp. 259-281. doi:10.2307/3546011

[53] F. Vendramini, S. Díaz, D. E. Gurvich, P. J. Wilson, K. Thompson and J. G. Hodgson, "Leaf Traits as Indicators of Resource-Use Strategy in Floras with Succulent Species,” New Phytologist, Vol. 154, 2002, No. 1, pp. 147157.

[54] Ü. Niinemets, "Components of Leaf Dry Mass per AreaThickness and Density-Alter Leaf Photosynthetic Capacity in Reverse Directions in Woody Plants," New Phytologist, Vol. 144, No. 1, 1999, pp. 35-47. doi:10.1046/j.1469-8137.1999.00466.x

[55] J. R. Ehleringer, "Ecology and Ecophysiology of Leaf Pubescence in North American Plants,” In: E. Rodriguez, P. L. Healey and I. Mehta, Eds., Biology and Chemistry of Plant Trichomes, Plenum, New York, 1984, pp. 113-132.

[56] G. Karabourniotis and J. F. Bornman, "Penetration of UV-A and UV-B and Blue Light through the Leaf Tri- chome Layers of Two Xeromorphic Plants, Olive and Oak, Measured by Optical Fibre Probes,” Physiologia Plantarum, Vol. 105, No. 4, 1999, pp. 655-661. doi:10.1034/j.1399-3054.1999.105409.x

[57] K. Hikosaka, "Interspecific Difference in the Photosynthesis-Nitrogen Relationship: Patterns, Physiological Causes, and Ecological Importance,” Journal of Plant Research, Vol. 117, No. 6, 2004, pp. 481-494. doi:10.1007/s10265-004-0174-2

[58] C. R. Warren and M. A. Adams, "What Determines Rates of Photosynthesis per Unit Nitrogen in Eucalyptus Seedlings?” Functional Plant Biology, Vol. 31, No. 12, 2004, pp. 1169-1178. doi:10.1071/FP04115

[59] B. R. Maricle and P. B. Adler, "Effects of Precipitation on Photosynthesis and Water Potential in Andropogon gerardii and Schizachyrium scoparium in a Southern Mixed Grass Prairie,” Environmental and Experimental Botany, Vol. 72, No. 2, 2011, pp. 223-231. doi:10.1016/j.envexpbot.2011.03.011

[60] D. W. Lawlor, "Limitation to Photosynthesis in WaterStressed Leaves: Stomata vs. Metabolism and the Role of ATP,” Annals of Botany, Vol. 89, No. 7, 2002, pp. 871885. doi:10.1093/aob/mcf110

[61] O. Ghannoum, " $\mathrm{C}_{4}$ Photosynthesis and Water Stress," Annals of Botany, Vol. 103, No. 4, 2009, pp. 635-644. doi:10.1093/aob/mcn093

[62] M. C. Hall and J. H. Willis, "Divergent Selection on Flowering Time Contributes to Local Adaptation in $\mathrm{Mi}$ mulus guttatus Populations,” Evolution, Vol. 60, No. 12, 2006, pp. 2466-2477.

[63] D. B. Lowry, R. C. Rockwood and J. H. Willis, "Ecological Reproductive Isolation of Coast and Inland Races of Mimulus guttatus,” Evolution, Vol. 62, No. 9, 2008, pp. 2196-2214. doi:10.1111/j.1558-5646.2008.00457.x

[64] C. A. Wu, D. B. Lowry, L. I. Nutter and J. H. Willis, "Natural Variation for Drought-Response Traits in the Mimulus guttatus Species Complex,” Oecologia, Vol. 162, No. 1, 2010, pp. 23-33. doi:10.1007/s00442-009-1448-0

[65] S. A. Dudley, "Differing Selection on Plant Physiological Traits in Response to Environmental Water Availability: A Test of Adaptive Hypotheses,” Evolution, Vol. 50, No. 1, 1996, pp. 92-102. doi:10.2307/2410783

[66] M. S. Heschel, S. E. Sultan, S. Glover and D. Sloan, "Population Differentiation and Plastic Responses to Drought Stress in the Generalist Annual Impatiens capensis,” Oecologia, Vol. 139, No. 4, 2004, pp. 487-494.

[67] F. Ludwig, D. M. Rosenthal, J. A. Johnston, N. C. Kane, B. L. Gross, C. Lexer, L. H. Rieseberg and L. A. Donovan, "Selection on Leaf Ecophysiological Traits in a Desert Hybrid Helianthus Species and Early-Generation Hybrids," Evolution, Vol. 58, No. 12, 2004, pp. 2682 2692.

[68] M. S. Heschel and C. Riginos, "Mechanisms of Selection for Drought Stress Tolerance and Avoidance in Impatiens capensis," American Journal of Botany, Vol. 92, No. 1, 2005, pp. 37-44. doi:10.3732/ajb.92.1.37 